\title{
Gerardo Ramírez Vidal y Manuel de Jesús Jiménez Moreno (eds.). Ensayos sobre retórica jurídica. México, IIFL, UNAM, 2019
}

\author{
Alberto J. Montero \\ Universidad Nacional Autónoma de México \\ Facultad de Derecho \\ amontero@derecho.unam.mx
}

Como resultado de la labor conjunta entre diversos investigadores de los Institutos de Investigaciones Filológicas y Filosóficas, así como académicos de la Facultad de Derecho, todos de la UNAM, cada año, desde hace seis, se celebra el Coloquio de Retórica, Argumentación e Interpretación Jurídicas, al cual concurren expertos en estas disciplinas provenientes de diversas entidades académicas de esta Universidad, así como de otras universidades nacionales y extranjeras. Fruto de esos encuentros académicos es la obra Ensayos sobre retórica jurídica, coordinada por el doctor Gerardo Ramírez Vidal y el maestro Manuel de Jesús Jiménez Moreno, de reciente aparición.

Como bien nos hacen saber sus editores en la presentación, la obra está conformada por diversos temas que tienen como hilo conductor a la retórica jurídica, tanto en su dimensión teórica como en la práctica. Afirma Chaim Perelman que en Grecia durante el periodo clásico la retórica fue una disciplina cultivada en los distintos ámbitos en que era necesario el dominio del lenguaje y del diálogo: la política, el derecho y la filosofía. Omito aquí las disputas entre los sofistas con Sócrates y Platón; baste recordar que en gran medida muchos prejuicios respecto a los sofistas como maestros de ardides, creadores de argumentos falaces, mercaderes del saber, etc., se lo debemos a estos dos filósofos atenienses; semejantes acusaciones se hicieron también en la modernidad, afirmando que eran saberes de tipo ornamental que no abonaban nada al conocimiento verdadero de la realidad.

No obstante, la retórica sobrevivió a los griegos y fue cultivada en Roma, donde el talento de Cicerón la convirtió en un saber imprescindible para la práctica judicial; cito a Ramírez Vidal, "los abogados desprecian a Cicerón, el hermano mayor de los abogados, si no es que su patrono; y al hacerlo se desprecian a sí mismos [...] no se es abogado si no se es orador, y no se es gran orador sin los conocimientos del derecho civil" (19). La retórica llegó a Bizancio y se tuvo entre los saberes fundamentales durante todo el medioevo; sin embargo, con el predominio de la razón científica, desde Des- 
cartes y los avances científicos en el siglo XIX, fue relegada como un arte no útil ya que no indagaba sobre lo verdadero en la realidad.

Si bien en el siglo XVIII Giambattista Vico mostró la necesidad de dotar al derecho de la belleza, así como del dominio del lenguaje, de los cuales los juristas romanos hicieron gala, fue hasta mediados del siglo xx que la retórica fue rescatada y volvió al catálogo de las asignaturas necesarias para el ejercicio correcto de diversas disciplinas, entre ellas el derecho. La retórica resurgió en el contexto de las necesidades del Estado y el derecho contemporáneos, siendo uno de sus principales temas lo relativo a la justicia, lo cual no puede expresarse en términos de una estricta racionalidad lógica. Al respecto es oportuno citar la afirmación de Dorantes Díaz acerca de que la retórica y la justicia coexisten si consideramos a la primera "como un método de integración y confrontación de argumentos y no como una forma de ocultar o trasgredir la verdad (55)"; también vale la pena mencionar, como afirma Suárez Romero, que hay problemas persistentes, más allá de las evidentes diferencias que existen entre la forma de organización políticojurídica de los griegos, los romanos y el Estado contemporáneo; uno de ellos es el que se pregunta: ¿qué es mejor y más conveniente, tener buenas leyes o tener buenos gobernantes?, a lo que los filósofos griegos respondieron, después de analizar con detalle diversas posibilidades, que son necesarios los buenos hombres, así como es imprescindible contar con buenas leyes que sujeten a todos; pregunta que la teoría constitucional también se formula y que encuentra en la retórica y el derecho los medios para ofrecer una respuesta adecuada.

La obra que reseñamos posee la virtud, sin duda podemos emplear este valor, de mostrar diversas aristas de la retórica que hoy en día se practica en los ámbitos legislativo, judicial y académico del derecho. Ejemplo de ello es el trabajo de Platas Pacheco, quien analiza las diferencias entre el argumento retórico y el argumento dialéctico y su aplicación en el proceso judicial; así como el de Raymundo Gama, quien indaga respecto de la influencia recíproca que existe entre la retórica y el derecho, y cómo en la retórica las presunciones cumplen la función de ser puntos de partida para desarrollar el argumento, o cómo las aseveraciones que se tienen por ciertas hasta demostrar su falsedad han incidido en el derecho, donde en los procesos judiciales han adquirido un carácter más complejo dando origen a una variedad de formas de comprender aquello que se presume como cierto y que requiere ser desvirtuado, lo cual implica a su vez tanto las actuaciones judiciales como las pruebas. Fonseca Luján por su parte, expone las relaciones entre las etapas de la audiencia del juicio oral y el proceso retórico; Galindo Sifuentes nos muestra cómo aprovechar las recomendaciones del discurso retórico para estructurar los discursos de apertura y clausura. En todas estas aportaciones apreciamos el sentido práctico que destaca a la retórica y por tanto su inmediata aplicación.

Retomo la idea de que la ciencia del derecho del siglo XIX separó al derecho 
de la retórica, barrera que se ha franqueado a grado tal que las aproximaciones entre ambas disciplinas vuelven a adquirir la fortaleza que otrora tuvieran; al respecto, son necesarias nuevas teorías para dar cuenta de lo complejo de esas relaciones, y en esto consiste el trabajo de Pedro Parini, quien a partir de Ottmar Ballweg y los diferentes niveles de la retórica - material, práctica y analítica- propone que la retórica del derecho sea estudiada analíticamente mediante la fronética, la holotática y la semiótica.

Referimos al inicio de esta reseña a los sofistas, y ahora es menester recuperar su imagen como la de aquellos educadores que cultivaban el arte, la virtud del bien hablar y del disertar; sobre esto, Zárate Ruiz refiere, a partir de su experiencia, cómo en los college estadounidenses se deben cursar materias en las que la retórica es el núcleo central que conforma sus saberes y práctica, lo cual es esencial para el posterior proceso formativo; San Vicente Parada nos muestra la necesidad de que el abogado del siglo xxi desarrolle habilidades para la comunicación asertiva, lo cual precisa el conocimiento y práctica de la retórica, pues esta favorece el aprendizaje significativo, crítico y creativo; afirma Parada que "para tener buenos abogados debe haber buenos docentes. Como el buen orador, el buen abogado y el buen docente tienen que contar con un discurso que motive, que mueva. El docente comprometido no es aquel que todo lo sabe, sino aquel que entusiasma a los alumnos" (155). Afín al tema de la educación, Cruz Parcero señala algunas de sus deficiencias en el ámbito del derecho como el que "no se centra en formar y desarrollar habilidades que son necesarias para un buen jurista: desde saber escribir, saber expresar bien sus ideas, saber argumentar y analizar argumentos, saber cómo interpretar leyes..." (183); también se refiere a los retos que debe enfrentar la argumentación jurídica en México, y señala que las habilidades argumentativas, no siendo las únicas, sí son importantes para formar buenos juristas.

Cierra la obra el trabajo de Jiménez Moreno, quien nos muestra las relaciones que existen entre la literatura y el derecho a propósito de Julio Torri y su tesis, elaborada para obtener el título de licenciado en derecho en 1913, titulada Breves consideraciones sobre el juicio verbal.

\section{Alberto J. Montero}

Profesor de carrera de tiempo completo definitivo en la Facultad de Derecho de la UNAM. Licenciado en Derecho y en Filosofía por la UNAM. Maestro en Historia de México en el Posgrado de Historia, también de la unAm. Autor de las obras: Derecho y moral. Estudio introductorio y Pensar al derecho. Dos ensayos sobre ética y derecho, ambas publicadas por la UNAM, y del libro Existencialismo y cristianismo. Ha sido conferencista y ponente en encuentros académicos en diversas universidades tanto en México como en el extranjero. 